\title{
Direction of Sustainable Development Policy in the Water Catchment Areas (Watershed) Koto Panjang Reservoir
}

\author{
Khairani $^{1(*)}$, Indang Dewata ${ }^{2}$, and Dilla Angraina ${ }^{1}$ \\ ${ }^{1}$ Department of Geography, Universitas Negeri Padang,, Indonesia \\ ${ }^{2}$ Department of Biology, Universitas Negeri Padang, Indonesia \\ *Corresponding author.Email: khairani@unp.ac.id
}

\begin{abstract}
This research aims to create the Direction of Sustainable Development Policy in the Water Catchment Areas (watershed) Koto Panjang Reservoir based on social and cultural study. This research type is qualitative research by using the interview data collection technique, observation and Focus Group Discussion. The data obtained were analyzed using the Analytical Hierarchy Process (AHP) with the help of expert choice software. The result showed that in determining the direction of the policy based on social and cultural studies obtained 4 criteria, namely economic, environment, social and cultural. Furthermore, resulting from 11 policy alternatives produced 5 policy priorities : (1) Management of water resources through conservation, development, use and control of water damage; (2) Combining the protection of environmental conservation with natural disasters; (3) Optimizing the function of river water utilization for social and economic interests through socialization of the division of the utilization zone of reservoir water bodies; (4) Increasing tourism promotion and tourism of the beauty of the reservoirs by involving the community in developing tourism activities to absorb local human resources; and (5) Community economic empowerment through eco-tourism, traditional handicrafts and local culinary specialties; with their respective values: $12,9 \% ; 11,8 \% ; 11,5 \% ; 10 \%$; and $9,70 \%$.
\end{abstract}

\section{Keywords: Water Catchment Area, Policy, Social Cultural}

\section{INTRODUCTION}

Development not only has a positive impact on reducing inequality, but also has a negative impact in the form of exploitation of natural resources and environmental degradation. Over time, the economic development that is usually measured by economic growth coupled with the fulfillment of social needs must be aligned with environmental concerns (Rasic, et al., 2012), because environmental quality affects and is affected by economic development (Todaro \& Smith, 2011b). As in the case in Lima Puluh Kota District which is Water Catchment Areas that functions as an energy producer in the Koto Panjang Hydroelectric Power Plant Reservoir. Dam construction is carried out by utilizing water sources from the Kampar Kanan river and Batang Mahat. Koto Panjang Hydroelectric Power Plant Reservoir is able to produce $114 \mathrm{MW}$ of power from 3 turbines that are operating and supplying electricity in Sumatera interconnection. The operational of Koto Panjang Hydroelectric Power Plant Reservoir are highly dependent on flow discharges originating from Kampar Kanan and Batang Mahat rivers. The discharge of the Koto Panjang reservoir has experienced dynamic fluctuations over the past 20 years. Rainfall is the dominant factor affecting the Koto Panjang Reservoir water discharge.

Therefore, the Koto Panjang hydropower reservoir experienced problems such as drought during the dry season and flooding during the rainy season.

In addition to the environment, the existence of the reservoir will also affect the socio-cultural conditions of the surrounding community, because the condition of the community around the reservoir develops in accordance with the existence of the reservoir ecosystem. Based on the results of Khairani and Dewata's research (2018), it was found that the construction of a reservoir submerged 10 villages consisting of 8 villages in Riau Province and 2 nagari (villages) in West Sumatra Province, that it also indirectly eliminates the culture of the area such as changes in the function of mamak who used to control communal land, rumah gadang, pandampa graves and communal land of the community. In the construction of this hydropower reservoir, it requires the community to move to a new location, so that in the process of resettlement still encountered obstacles or 
community rights that have not been fulfilled, both in the process of negotiation, initial infrastructure development, and implementation of the resettlement. As a result of the relocation, many people living around the reservoir area lost productive land that has been passed down from generation to generation, so that most of them have gardening livelihoods such as palm oil, rubber and gambir (hungry wood), and depend their livelihoods on the forest to search for firewood. In addition, the community around the reservoir also conducts aquaculture through floating net cages. On the other hand, it also has a positive impact on the sociocultural life of the community, which is to broaden the community's perspective of expanding business opportunities and employment opportunities, increasing community income and the distribution of livable housing for each family head.

Based on the problems faced, it is known that the construction of the Koto Panjang hydropower reservoir is intended to improve the welfare of the community through the fulfillment of electrical energy sources, without realizing it has caused an impact on the lives of people living around the reservoir. To avoid these impacts, a policy is needed that integrates activities around hydropower reservoirs with broader enviromental aspects by balancing the relationship between socio-economic and cultural aspects and governance to achieve sustainable development.

The aim of this research is to formulate the direction of the sustainable development policy of the Water Catchment Areas of Koto Panjang Hydroelectric Power Plant by paying attention to social and cultural studies. These three indicators were chosen because in sustainable development good indicators must be able to represent the three pillars that are economic, social and environmental aspects (Pardi, Nawi, \& Salleh, 2016).

\section{METHOD}

The study was conducted for 4 months from May to October 2019 with the research location in Pangkalan Subdistrict, Limapuluh Kota District and Koto Kampar Subdistrict XIII, Kampar District. Data collection techniques used were interviews, observation, and Focus Group Discussion. Furthermore, the data were analyzed qualitatively and using the Analytical Hierarchy Process (AHP). The Analytical Hierarchy Process aims to determine policy priorities with the help of expert choice 11 software.

\section{RESULTS AND DISCUSSION}

Physical changes in Pangkalan Baru Subdistrict, Lima Puluh Kota District due to the existence of the Koto Panjang Hydroelectric Reservoir, have an impact on the social and cultural conditions of the community. Negative impacts can be seen from the rise of social disorder in the community and socio-cultural values that have disappeared such as rumah gadang, pandam pakuburan and communal land of the community, some of which are found in the forests around the reservoir. On the other hand the positive impact caused by the socio-cultural life of the community is adding to the community's insight into the expansion of business opportunities and employment, increasing community income and the distribution of livable housing for each family head. Anticipating the emergence of these negative impacts, the involvement / role of the government and Hydroelectric Power Plant is needed in the preservation and conservation of the catchment area.

The Focus Group Discussion held in collaboration with the Sumatra Ecoregion Development Control Center presented experts / experts is based on the Kampar River Watershed which has experienced a decline in quality in recent years, which affects the daily activities of people around it, so the commitment of all community sides is needed in improving the quality of the Kampar watershed in a sustainable manner.

The sustainable principles become a reference in the management of the Kampar sub-watershed, where the ecological, economic and socio-cultural functions of the resources in the watershed can be guaranteed in a balanced manner. Therefore, the FGD activity aims to ensure that the implementation of the sustainable Kampar watershed management program is carried out in an integrated manner where the preservation of river ecosystems can provide benefits (environmental services) for the community.

From the results of the FGD and interviews and research results in the previous year, this study produced 4 criteria which will be focused on developing policy directions based on the social and cultural conditions of the community, namely economic, environmental, social and cultural criteria. Furthermore, 11 alternative policies were obtained, namely (1) Increasing public awareness regarding waste, especially waste management; (2) Empowering the community's economy through ecotourism, promoting culture, traditional crafts and culinary specialties of the local area (3) Strict sanctions for anyone who carries out activities that have an impact on environmental damage, (4) Affirmations related to communal land ownership; (5) Management of water resources through conservation, development, use and control of water damage, (6) The enhancement of cultural tourism promotion (Muara Takus Temple which is often used for Buddhist religious rituals, calempong music, Balimau Kasai, and Gubano dzikir) and reservoir beauty tourism by involving the community in developing tourism activities to absorb local human resources; (7) Consolidation of protected areas and cultivation areas through the establishment of customary forests; (8) Integrating environmental conservation protection with natural disasters, (9) Developing an integrated and cooperative tourism area between the government and the tourism implementers directly, (10) Socialization of local wisdom to the surrounding community; and (11) Optimizing the function of river water utilization for social and economic interests through socialization of the classification of the reservoir water body utilization zones. The following are the resulting policy priorities :

(1) Management of water resources through conservation, development, use and control of water 
damaging forces; (2) Integrating the protection of environmental conservation with natural disasters; (3) Optimizing the function of river water utilization for social and economic interests through the socialization of the zones division of the reservoir water body utilization; (4)
Increasing tourism promotion and reservoirs beauty tourism of by involving the community in developing tourism activities to absorb local human resources;

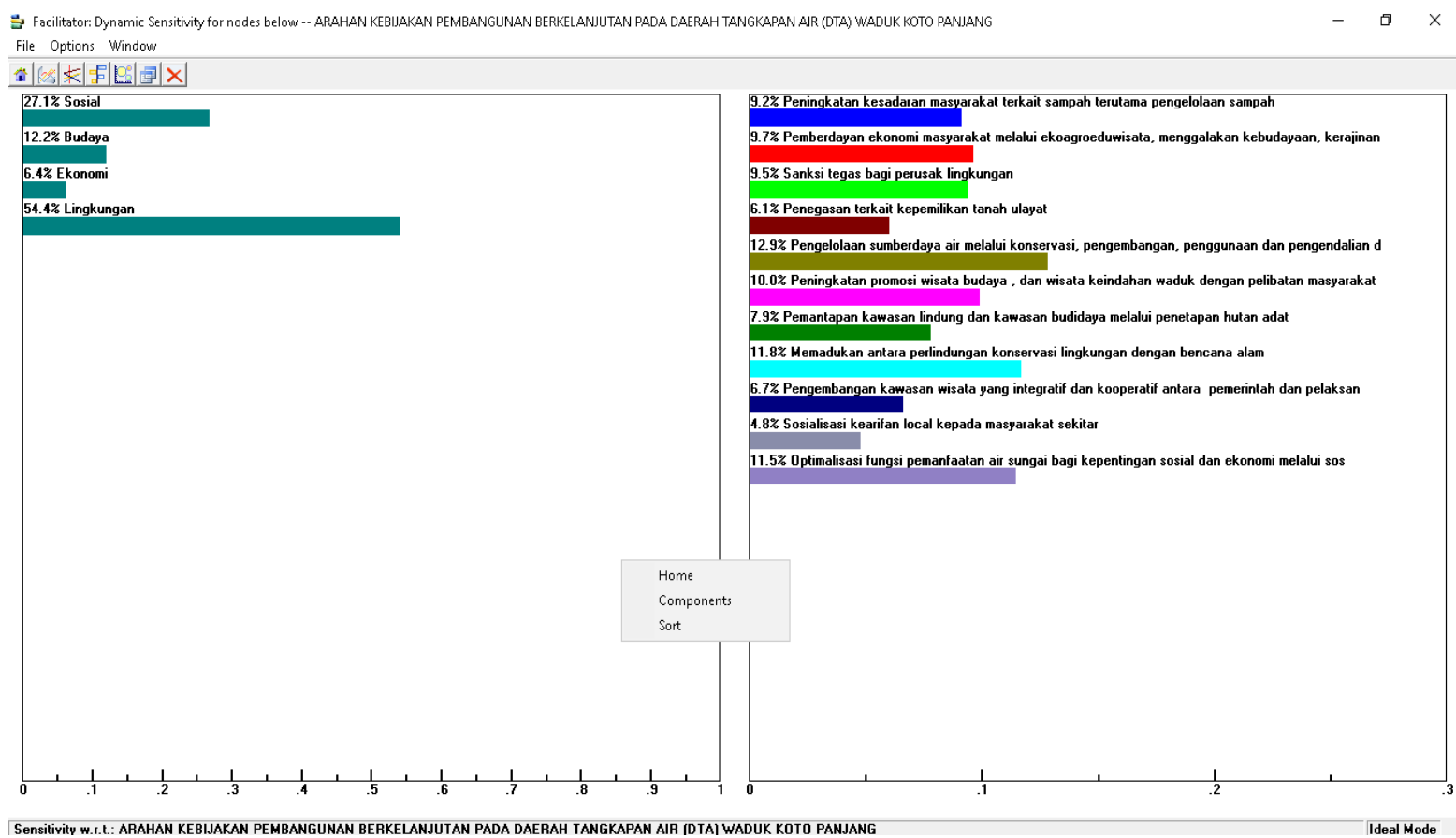

Figure 1. Policy priorities based on criteria evaluation

Then (5) Community economic empowerment through eco-agro-tourism, traditional crafts and culinary specialties of the local area; with a sequence value of $12.9 \%$ each; $11.8 \% ; 11.5 \%$; $10 \%$; and $9.70 \%$. The priority policy implementation can be carried out as follows:

1. Management of water resources through conservation, development, utilization and control of water damage forces.

a. Provides counseling to the community related to water resources.

b. Increase community knowledge about soiland water conservation

c. Changing the behavior of farmer farming patterns towards agricultural systems that follow the rules of conservation of land and water.

2. Integrating the protection of the environmental conservation with naturaldisasters.

a. Revive local wisdom, especially those related to the environment.

b. Workshops and outreach about potential natural disasters.

c. Public awareness on the importance of protecting the environment.

3. Optimizing the function of river water utilization for social and economic interests through the socialization of the zones division of the reservoir water body utilization a. The increase of the government cooperation with the community related to the function of river water utilization

b. Socialization for the community regarding the river utilization zones and what economic activities can be carried out.

c. Socialization and counseling for the community about how to use rivers properly without damaging the environment.

4. Increasing tourism promotion and reservoirs beauty tourism of by involving the community in developing tourism activities to absorb local human resources;

a. Arrange tour packages that will be provided and make the local community as a tour manager.

b. Good partnertship between the government, the private sector and the community in implementing cultural tourism and natural reservoir tourism.

c. Promotion of the Muara Takus Temple which is often used for Buddhist religious rituals, calempong music arts, balimau kasai, and gubano dhikr.

d. Revive lost cultures or traditions such as Alek Bakajang tradition which aims for a Strengthening the unity of the community $b$. Strengthening community gathering c. Increase Cooperation between communities. 
e. Strict sanctions for damaging reservoir environments.

5. Community economic empowerment through ecoagro-tourism, traditional crafts and culinary specialties of the local area

a. The use of land for the eco-agro-tourism program must have the approval of the landowners, both individuals and communal / clans.

b. Socializing gambier processing equipment that is in accordance with farmers' socio-economic conditions and nature-friendly, namely tools that use substitute fuels other than wood and are followed by guaranteed supplies.

c. Identify and develop traditional crafts and local specialties.

Based on the results of these priorities, the values or criteria for ecological, economic, social and cultural sustainability are part of the rules of sustainable development (Djajadiningrat, 1992) states that there are 8 principles in sustainable development, including ecological sustainability that guarantees the sustainability of the earth's existence through the integrity of the environmental order that is maintained through efforts to increase carrying capacity, assimilation, and the continued use of renewable resources; economic sustainability is related to sustainable economic prosperity, as well as increasing prosperity and distribution of prosperity; and SocialCultural Sustainability expressed in social justice, human dignity, and improving the quality of life for all humans. Thus, the 5 alternative policies based on social and cultural studies of the community emphasize ecological sustainability, where the ecology or the environment itself if damaged, severe deterioration in the ecosystem where humans live, the future human life will experience many difficulties, so that sustainable development not occur.

\section{CONCLUSIONS}

Sustainable development is a development process (land, city, business, community) that is principled to meet current needs without compromising the needs of future generations. Policy directions that can be a priority for local governments related to problems in the Koto Panjang Hydroelectric Power Plant based on community social cultural studies (1) Management of water resources through conservation, development, use and control of water damage; (2) Integrating the protection of environmental conservation with natural disasters; (3) Optimizing the function of river water utilization for social and economic interests through the socialization of the zones division of the reservoir water body utilization; (4) Increasing tourism promotion and reservoirs beauty tourism of by involving the community in developing tourism activities to absorb local human resources; dan (5) Community economic empowerment through eco-agrotourism, traditional crafts and culinary specialties of the local area; with a sequence value of $12.9 \%$ each; $11.8 \%$; $11.5 \% ; 10 \%$; and $9.70 \%$. The five policy priorities are, in general, emphasize more on the environment, where people are very dependent on the environment for their lives, so that if damaged, severe deterioration in the ecosystem where humans live, then human life will experience many difficulties in the future and sustainable development does not occur.

\section{REFERENCES}

[1] Djajadiningrat, S.T. 1992. Konsep Pembangunan Berkelanjutan dalam Membangun Tanpa Merusak Lingkungan. Kantor Menteri Negara Lingkungan Hidup.

[2] Pardi, F., Nawi, A. S., \& Salleh, A. M. 2016. Determining Factors Toward A Sustainable Development Path in Selected ASEAN Countries and JapanEvidence from Panel Data Analysis. International Journal of Bussiness and Information, 11.

[3] Rasic, K., Mulej, M., \& Cancer, V. 2012. The System of Indicators of Economic Growth for Better Quality of Life: Economic and Social Impacts, 31, 535-562.

[4] Todaro, M. P., \& Smith, S. C. 2011b. Pembangunan Ekonomi Jilid II. (A. Maulana, Ed.) (11th ed.). Jakarta: Penerbit Erlangga

[5] Walkowiak, E. 1996. Sustainable development as an economic development strategy. Economic Development Review, 75-77. 